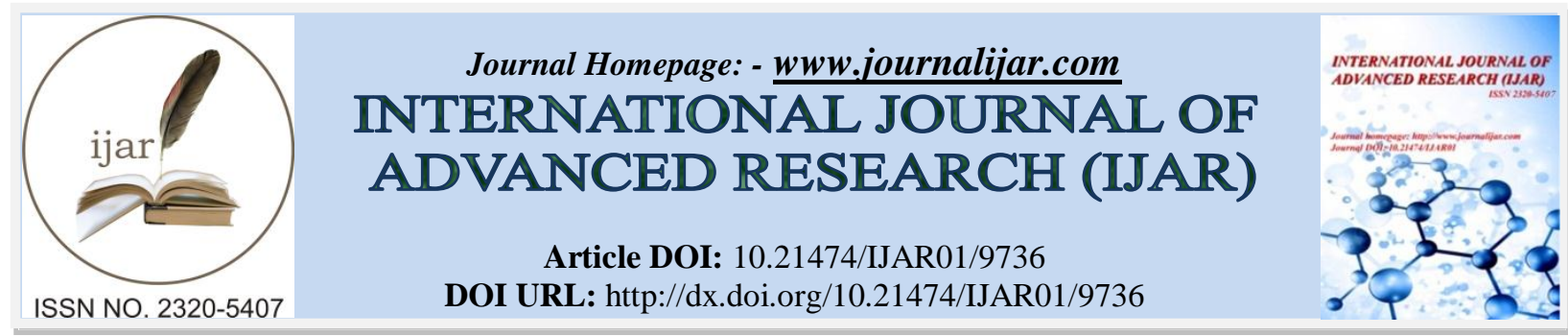

RESEARCH ARTICLE

\title{
COMPARISON OF NUTRITIONAL STATUS BETWEEN UNIVERSITY STUDENTS LIVING AT DORMITORY AND STUDENTS LIVING AT HOME.
}

\author{
Norah Eid Aljohani. \\ Department of Food Science and Nutrition, Taibah University, Al-Madinah Al-Munawarah, Kingdom of Saudi \\ Arabia.
}

\section{Manuscript Info}

Manuscript History

Received: 12 July 2019

Final Accepted: 14 August 2019

Published: September 2019

Key words:-

Nutritional, status, undergraduate, college, student, dormitory, female.

\section{Abstract}

Background: Transitioning into college can pose as an important challenge to a student's eating behaviors. The present study aim was to compare nutritional patterns between dormitory and non-dormitory female students in Taibah university, in Saudi Arabia also to assess the nutritional conditions of these students.

Method: This cross-sectional study was conducted among three hundred and two female undergraduate students at Taibah university, ages 18-22 years. One hundred and forty-seven of them have being lived in dormitory, as well as one hundred and fifty-five live with their families. Participants completed a self-administered three-day food record (FR) in addition to a structured questionnaire that included questions on socio-demographic characteristics, dietary habits, and physical activities. Also, anthropometric measurements were obtained. Data was analyzed using SPSS statistical package (version 22.0) and the level of significance was set at $\mathrm{p} \leq 0.05$.

Results: The results of this study showed that ninety one percent of the female students living at university dorms changed their dietary habits after joined to the university compared to fifty-six percent of the female students living at home with their families $(\mathrm{p}<0.05)$. Moreover, sixtyeight percent of dormitory female students and forty-one percent of those living at home with their families skipped breakfast. Also, the results showed a significant difference between dormitory and nondormitory female students in energy, protein, and dietary fiber consumption. Dormitory students consumed 148.9 calories more per day, 24.25 grams (g) of protein less per day, and 5.5 grams $(\mathrm{g})$ of dietary fiber less per day $(p \leq 0.05)$. Furthermore, only twenty-two percent of them consume protein daily.

Conclusion: Female students living in the university dorms were at a higher risk of developing unhealthy dietary habits. Launching Nutritional counseling offices to educate students on nutritional issues are important and providing a dining hall service is needed to help solve dietary problems inside dorms.

Copy Right, IJAR, 2019,. All rights reserved.
Corresponding Author:-Norah Eid Aljohani.

Address:-Department of Food Science and Nutrition, Taibah University, Al-Madinah AlMunawarah, Kingdom of Saudi Arabia. 


\section{Introduction:-}

College students often face some challenges, one of these challenges being lifestyle changes such as transfers to new schools or moving without family to a different place in order to join to a university (1). This is common especially for Saudi female students because there are some obstacles facing them due to the conservative culture for Saudi females in general. Some of Saudi's females have to live in dorms after accepting a college admission whereas these dorms have limited resources in terms of accessing high quality food in general and healthy food in particular. Also, on campus, they are facing unhealthy food choices, which in turn, can lead to development of unhealthy eating habits.

Dietary patterns during the period of college could be affected by lifestyle change. Also, people's eating patterns is an extension of healthy eating during college periods (1). Moreover, college students are often affected by environments that depend on unhealthy snacking, skipping and irregular meal patterns especially for students living in dorms (2). Unhealthy lifestyle in this period of life is associated with diet-related chronic diseases later in life such as diabetes, obesity, osteoporosis, and hyperlipidemia (3). The purpose of this study was to compare these nutritional patterns between dormitory and non-dormitory students at Taibah University in Saudi Arabia as well as to examine the nutritional status of those college students.

\section{Methodology:-}

\section{Study Design}

The study applied a cross- sectional, conducted between November 2018 and February 2019.

\section{Study Area}

The study was carried out in Taibah University, Al-Madinah City, which is situated on the eastern part of the Al Hijaz region in the west side of the Kingdom of Saudi Arabia. Taibah University is a public comprehensive University. Taibah University was chosen as the recruitment site for this study.

\section{Study Population}

The study population included female undergraduate students of Taibah University.

\section{Sample Size}

Using $\mathrm{G}^{*}$ Power statistical software, a priori power analysis indicated that a sample size of 126 was needed it from each group (dormitory and non-dormitory students) to reliably detect medium effect size of 0.15 with alpha of 0.05 and desired statistical power level of 0.80 (4). Thus, study sample of 302 was successfully recruited.

\section{Sample}

Female college students between 18 and 22 years of age (147 dormitory students and 155 non-dormitory students) from Taibah University were recruited in this study by using announcements on University boards to invite students to participate in the study. None of the participants had any significant medical problems nor were they taking any medication.

\section{Data Collection Method}

Appointments were scheduled to take the measurements of height, weight, and waist circumferences of the students in order to explain study methods to participants. Weight and height measurements were taken by using SECA 703 Digital Medical Column Scale with a stadiometer attached to the scale. Weight was measured to the nearest 0.1 kilogram (kg) using a digital balance and height was measured by a stadiometer to the nearest 0.1 centimeter. Body mass index (BMI) was calculated as the ratio of body weight to height squared and expressed in $\mathrm{kg} / \mathrm{m}^{2}$. A selfadministered three days Food Record (FR) was used to obtain dietary intake (5) as well as a self-administered structured questionnaire that included questions on socio-demographic characteristics, dietary habits, physical activities (6).

\section{Food Intakes Analysis}

Dietary intakes were analyzed for nutrient content using the Food Processor Plus computer program software (ESHA). The ESHA master database is composed of 50,000 food items (7). For foods that were not found in the software, Saudi Arabian tables were used (8). 


\section{Statistical Analysis:-}

The Statistical Product and Service Solutions (SPSS) software version 20 was used for the data analysis (9). Prior to the analysis, data was screened for normality and outliers. An independent student t-test was used to compare quantitative variables and a chi square test was used to compare categorical variables. All the tests were two-tailed. The statistical significance was considered at $\mathrm{P} \leq 0.05$.

\section{Ethical Consideration}

Ethical approval for this study was obtained from the Protection of Human Subjects Committee, Taibah University (TU). Protocol Number TUCDREC/ 20181021 on September 27, 2018. Permission was obtained from the school management and from the participants by using informed consent forms (ICF). Participants were informed that their personal data would be protected, and they could withdraw at any time from the study.

\section{Results:-}

The study sample included 302 female undergraduate students, 147 (48.6\%) of which were dormitory students and $155(51.4 \%)$ of which were non dormitory students. Table 1 shows the demographics of 302 participants by group (dormitory students and non- dormitory students). No significant differences were observed in baseline characteristics between both groups.

Table 1:-Demographics (dormitory students and non- dormitory students)

\begin{tabular}{|l|l|l|l|}
\hline & & $\begin{array}{l}\text { Dormitory students } \\
\text { N=147 } \\
\text { n } \%)\end{array}$ & $\begin{array}{l}\text { Non-dormitory stude } \\
\text { N=155 } \\
\text { n (\%) }\end{array}$ \\
\hline Age (years): mean (SD) & & $18.22(0.88)$ & $18.90(0.82)$ \\
\hline Waist circumference: mean (SD) & & $71(4.6)$ & $73(6.7)$ \\
\hline Hip circumference: mean (SD) & & $95(7.4)$ & $98(7.9)$ \\
\hline Income (Saudi Riyal) & $<5000$ & $19(12.9)$ & $11(7.09)$ \\
\hline & $5001-7000$ & $39(26.5)$ & $54(34.8)$ \\
\hline & $7001-9000$ & $44(29.9)$ & $43(27.7)$ \\
\hline & $>9000$ & $17(11.5)$ & $14(9.03)$ \\
\hline Taking vitamin & Prefer not to answer & $28(19.04)$ & $33(20.6)$ \\
\hline & No & $96(65.3)$ & $109(70.3)$ \\
\hline Food allergy & Yes & $51(34.6)$ & $46(29.6)$ \\
\hline & No & $131(89.2)$ & $144(92.9)$ \\
\hline Health issue & Yes & $16(10.8)$ & $11(7.09)$ \\
\hline & No & $128(87.07)$ & $129(83.2)$ \\
\hline BMI category & Yes & $19(12.2)$ & $16(15.7)$ \\
\hline & Underweight & $29(19.72)$ & $32(20.6)$ \\
\hline & Normal weight & $84(57.1)$ & $94(60.6)$ \\
\hline & Overweight & $30(20.4)$ & $27(17.4)$ \\
\hline Physical activity & Obesity & $4(2.7)$ & $2(1.2)$ \\
\hline & Lightly active & $97(65.9)$ & $103(66.4)$ \\
\hline & Moderately active & $45(30.6)$ & $33(21.2)$ \\
\hline & Very active & $5(3.4)$ & $19(12.2)$ \\
\hline & & &
\end{tabular}

$\mathrm{P} \leq 0.05$. Saudi Riyal $=0.27$ U.S. dollars

In this study we found that modifying eating habits after joining the university was significantly more common among female students living at the university dorms, 134 students $(91.1 \%)$ than among female students living at home with families, 87 students $(56.1 \%)$ ( $\mathrm{p}<0.05)$. Also, ninety-four $(63.9 \%)$ of the female students who live at the university dorms ate two main meals in a day and ninety-six (61.9\%) of those who live at home with their families ate three main meals daily. The usual source of food for a higher proportion of those living at university dorms 108 students (73.4\%) were purchased only and 126 students (81.2\%) were prepared only of those who live at home with their families $(\mathrm{p}<0.05)$. More than a half of dormitory female students $101(68.7 \%)$ and less than a half of those living at home with their families 64 students (41.2\%) skipped breakfast. Most dormitory female students 131 
(95.9\%) and students living at home with their families $145(93.5 \%)$ ate snacks $(\mathrm{p}<0.05)$. One hundred and twentysix $(82.7 \%)$ of those living at university dorms and one hundred and eighteen $(76.1 \%)$ of those living at home with their families ate in between meals.

Table 2:-Meal Pattern and Change in Eating Habits

\begin{tabular}{|c|c|c|c|c|}
\hline Variables & & $\begin{array}{c}\text { Dormitory } \\
\text { Students } \\
\mathrm{N}=147 \\
\mathrm{n}(\%)\end{array}$ & $\begin{array}{c}\text { Non-dormitory } \\
\text { Students } \\
\mathrm{N}=155 \\
\mathrm{n}(\%)\end{array}$ & $\mathrm{P}$ value $^{\mathrm{a}}$ \\
\hline \multirow{3}{*}{$\begin{array}{l}\text { Change in Eating } \\
\text { Habits }\end{array}$} & Yes, a lot & $134(91.1)$ & $87(56.1)$ & $0.05^{*}$ \\
\hline & Yes, but not much & $12(8.1)$ & $47(30.3)$ & \\
\hline & No & $1(0.6)$ & $21(5)$ & \\
\hline \multirow{4}{*}{$\begin{array}{l}\text { Number of main } \\
\text { meals in a day }\end{array}$} & 1 & $29(19.7)$ & $10(6.4)$ & NS \\
\hline & 2 & $94(63.9)$ & $33(21.2)$ & \\
\hline & 3 & $24(16.3)$ & $96(61.9)$ & \\
\hline & $>3$ & 0 & $16(10.32)$ & \\
\hline \multirow{3}{*}{$\begin{array}{l}\text { Usual source of food } \\
\text { meals }\end{array}$} & Prepared only & $5(3.4)$ & $126(81.2)$ & NS \\
\hline & Purchased only & $108(73.4)$ & $18(11.6)$ & \\
\hline & Both & $34(23.1)$ & $11(7.09)$ & \\
\hline \multirow[t]{2}{*}{ Breakfast skipping } & Yes & $101(68.7)$ & $64(41.2)$ & $0.05^{*}$ \\
\hline & No & $46(31.29)$ & $91(48.7)$ & \\
\hline \multirow{2}{*}{$\begin{array}{l}\text { Eats in between } \\
\text { Meals }\end{array}$} & Yes & $126(85.7)$ & $118(76.1)$ & NS \\
\hline & No & $21(14.2)$ & $37(23.8)$ & \\
\hline \multirow[t]{2}{*}{ Eats snacks } & Yes & $131(95.9)$ & $145(93.5)$ & $0.05^{*}$ \\
\hline & No & $6(4)$ & $10(6.4)$ & \\
\hline
\end{tabular}

Chi-square analysis of differences between groups. $* \mathrm{P} \leq 0.05$

Comparing the mean dietary intake of nutrients between dormitory and non-dormitory female students (Table 3) showed that dormitory female students consumed more energy (2098.3 Calories), consumed less protein (62.25 g), and less dietary fiber $(32.7 \mathrm{~g})$. The differences were statistically significant at $(\mathrm{p} \leq 0.05)$.

Table 3:-Mean dietary intake of energy and nutrients in dormitory students compared with non- dormitory students

\begin{tabular}{|l|l|l|l|}
\hline Nutrient & Dormitory students (N =147) & Non-dormitory students (N =155) & P value $^{\text {a }}$ \\
\hline & Mean (SD) & Mean (SD) & \\
\hline Energy (Cal) & $2098.3(443.1)$ & $1949.4(338.4)$ & $0.05^{*}$ \\
\hline Protein $(\mathrm{g})$ & $62.25(34.5)$ & $86.5(28.1)$ & $0.01^{*}$ \\
\hline Carbohydrate $(\mathrm{g})$ & $277.2(96.9)$ & $232.5(101.3)$ & $\mathrm{NS}$ \\
\hline Fat $(\mathrm{g})$ & $71.5(43.0)$ & $85.6 .5(31.3)$ & $\mathrm{NS}$ \\
\hline Saturated Fat $(\mathrm{g})$ & $54.4(10.7)$ & $43.9(12.1)$ & $\mathrm{NS}$ \\
\hline Polyunsaturated $(\mathrm{g})$ & $11.2(3.9)$ & $8.9(2.5)$ & $\mathrm{NS}$ \\
\hline Monounsaturated(g) & $13.1(4.2)$ & $9.2(4.3)$ & $\mathrm{NS}$ \\
\hline Cholesterol $(\mathrm{mg})$ & $354.4(112.4)$ & $301(132.0)$ & $\mathrm{NS}$ \\
\hline Dietary Fiber $(\mathrm{g})$ & $32.7(13.8)$ & $38.2(13.5)$ & $0.05^{*}$ \\
\hline
\end{tabular}

Independent student t-test. $* \mathrm{P} \leq 0.05$

Table 4 shows the basic food group consumptions among dormitory and non-dormitory female students. The daily food consumption from meat and meat's alternatives (27.7\%), milk (26.7\%), vegetables $(27.9 \%)$, fruit $(24.4 \%)$, bread and bread's alternatives $(89.03 \%)$, and rice and other cereals $(85.1 \%)$ were higher among non-dormitory students. Moreover, dormitory female students consumed more sweets and fatty foods daily $(71.4 \%)$. 
Table 4:-Basic food groups consumptions among dormitory and non-dormitory students

\begin{tabular}{|c|c|c|}
\hline Food Groups & $\begin{array}{l}\text { Dormitory Students } \mathrm{N}=147 \\
\mathrm{~N}(\%)\end{array}$ & $\begin{array}{l}\text { Non-Dormitory Students N=155 } \\
\mathrm{N}(\%)\end{array}$ \\
\hline \multicolumn{3}{|c|}{ Meat and meat's alternatives } \\
\hline Daily & $33(22.4)$ & $43(27.7)$ \\
\hline$>3$ days & $26(17.6)$ & $90(58.06)$ \\
\hline Weekly & $88(59.8)$ & $22(14.19$ \\
\hline \multicolumn{3}{|l|}{ Milk } \\
\hline Daily & $24(16.3)$ & $43(26.7)$ \\
\hline$>3$ days & $56(38.09)$ & $85(54.8)$ \\
\hline Weekly & $67(45.5)$ & $27(17.4)$ \\
\hline \multicolumn{3}{|l|}{ Vegetables } \\
\hline Daily & $15(10.2)$ & $42(27.09)$ \\
\hline$>3$ days & $39(26.5)$ & $95(61.2)$ \\
\hline Weekly & $93(63.2)$ & $18(11.61)$ \\
\hline \multicolumn{3}{|l|}{ Fruits } \\
\hline Daily & $18(12.2)$ & $38(24.4)$ \\
\hline$>3$ days & 44 (29.9) & $105(67.7)$ \\
\hline Weekly & $85(57.8)$ & $12(7.7)$ \\
\hline \multicolumn{3}{|c|}{ Bread and bread's alternatives } \\
\hline Daily & $94(63.9)$ & $138(89.03)$ \\
\hline$>3$ days & $53(36.05)$ & $17(10.07)$ \\
\hline Weekly & $0(0.0)$ & $0(0.0)$ \\
\hline \multicolumn{3}{|c|}{ Rice and another cereal } \\
\hline Daily & $55(37.4)$ & $132(85.1)$ \\
\hline$>3$ days & $76(51.7)$ & $15(9.6)$ \\
\hline Weekly & $16(10.8)$ & $8(5.16)$ \\
\hline \multicolumn{3}{|c|}{ Sweets and fatty foods } \\
\hline Daily & $105(71.4)$ & $92(59.3)$ \\
\hline$>3$ days & $34(23.1)$ & $46(23.2)$ \\
\hline Weekly & $8(5.44)$ & $27(17.41)$ \\
\hline
\end{tabular}

\section{Discussion:-}

Poor dietary behaviors are related to obesity especially in college populations. This study's results examined the content of nutrients in non-dormitory states compared with dormitory living conditions which is eating habits can be influenced by moving away from home and family. Living in dorms away from family might be related to significant negative changes in food habits besides the fact that students living in dorms are often at higher risk of consuming unhealthy foods and not having optimal nutritional status (10). Among female college students might be more important because of the serious consequences of undernutrition, such as deficiencies of vitamins and minerals that might lead to anemia.

This study shows that there were statistically significant differences between dormitory and non-dormitory female undergraduate students in the mean energy intake and macronutrients, however the energy and macronutrients intakes were normal. This finding was consistent with the results of Mirzaeian et al, study in 2013 among female students of Isfahan University of Medical Sciences dormitories in Iran (11). Also, protein consumptions were lower in dormitory female students compared to non-dormitory which is consistent to Hajiahmadi et al., (12). That might be due to food availability inside the dorm. On the other hand, this result is not consistent with a previous study 
which was conducted by Tarighat et al. The study showed that protein consumptions were higher in dormitory students compared to non-dormitory students (13).

Skipping breakfast, which is the most important meal of the day, was common among female students living at university dorm than among female students living at home. This result is consistent with other studies such as Peltzer and Pengpid (14) and Vancelik et al., (15). This might be due to the shortness of time as the underlying reason. Female students living in university dorms have limited time for breakfast in order to use scheduled transportation services to be able to attend the early morning lectures and seminars (16). Also, that might be due to not having healthy food options available inside the dorms. In order to encourage healthy eating habits in dormitory female students, dormitory administrations should provide healthy breakfast, lunch and dinner options. Furthermore, providing easily accessible and healthy breakfast at university cafeterias for all students is recommend.

There is a lower intake of meat and meat's alternatives, milk, vegetables, fruit, bread and bread's alternatives, rice and other cereals and higher intakes of sweets and fatty foods from female students residing in the dormitory compared to non-dormitory students. That is consider an unhealthy dietary habit as well as the irregularity of the meals. This finding was consistent with Alghamid and et al., study; researchers found that students living at six Saudi Universities dorms (King Abdulaziz University, King Khalid University, King Saud University, King Faisal University, Umm Al-Qura University, and King Fahd University) were at higher risk after joining the university resulting into unhealthy dietary habits. Moreover, more than a half of the students living at university dorms reported main changes in dietary habits (17). Also, this study finding is similar to the findings from other studies. For instance, in Saudi Arabia at Rass, Qassim University (18), in Kuwait University, Kuwait city, Kuwait (19), in university of medical sciences, Hamadan, Iran (20), and in University of Salento, Lecce, Italy (21).

\section{Conclusion:-}

The results of this study showed that female dormitory students don't have ideal practice toward dietary habits. Thus, nutrition education is an important influence on their healthy eating habits. In order to maintain the optimal nutritional status, nutritional counseling offices are essential. Moreover, students should be educated on the importance of breakfast and having a balanced diet.

\section{Competing Interests Statement}

The author declares that there are no competing or potential conflicts of interest.

\section{Acknowledgement:-}

I would like to acknowledge and thank Taibah University for allowing me to conduct my research.

\section{References}

1. Perusse-Lachance, E., Tremblay, A., Drapeau, V. (2010). Lifestyle factors and other health measures in a Canadian university community. Applied Physiology, Nutrition, and Metabolism; 35(4): 498-506.

2. Fedewa, M., Das, B., Evans, E., and Dishman, R. (2014). Change in weight and Adiposity in college students. American Journal of Preventive Medicine, 47(5), 641-652.

3. Smith, M., Dickerson, J., Sosa, E., McKyer, J., Lisako, E., Ory, M. (2012). College students’ perceived disease risk versus actual prevalence rates. American Journal of Health Behavior, 36(1): 96-106.

4. Faul, F., Erdfelder, E., Buchner, A., and Lang, A. (2009). Statistical power analyses using G*Power 3.1: Tests for correlation and regression analyses. Behavior Research Methods, 41: 1149-1160.

5. Thompson, F., and Byers, T. (1994). Dietary assessment resource manual. Journal of Nutrition, 124: 2245S2317S.

6. Bagordo, F., Grassi, T., Serio, F., Idolo, A., and De Donno, A. (2013). Dietary habits and health among university students living at or away from home in southern Italy. Journal of Food and Nutrition Research, 52(3), 164-171

7. The Food Processor Plus computer program software (ESHA Version 0.7; Salem, Oregon, 2007).

8. Al Nozha, M., Al-Kanhal, M., Al-Othaimeen, A, Al-Mohizea I, Osman, A, and Al-Shammary A. Evaluation of the Nutritional Status of the People of Saudi Arabia. (1996). Final Report. Riyadh (KSA): King Abdul Aziz City for Science and Technology (KACST).

9. The Statistical Product and Service Solutions SPSS Inc. SPSS 20.0 for Windows Evaluation. Chicago: SPSS Inc, 2011. 
10. Kattelmann, K., Bredbenner, C., White, A., Greene, G., Hoerr, S., Kidd, T. (2014). The effects of Young Adults Eating and Active for Health (YEAH): a theory-based Web-delivered intervention. Journal of Nutrition Education and Behavior, 46(6), S27-41.

11. Mirzaeian, S., Ghavami, R., Sadeghian, F., Sheikhi, M., Khosravi, Z Askari, G., Sirenian., A, and Yadegarfar, G. (2013). Assessing the micronutrient and macronutrient intakes in female students and comparing them with the set standard values. Journal of Education and Health Promotion.2:1.

12. Hajiahmadi, M., Kaboodi, P., Ebrahimpour., S, Taghavi., H, and Ramazannejad S.(2018). A Study of nutritional status of dormitory and non-dormitory female students in Babol University of Medical Sciences. International Journal of Advanced Biotechnology and Research. 9 (2): 365-369

13. Tarighat., A, Mahdavi., R, Ghaemmaghami., J, Saafaian., A. (2003). Comparing Nutritional Status of College Female Students Living on and off Campus in Ardabil. Journal of Ardabil University of Medical Sciences. 3(3): 44-52.

14. Peltzer, K., Pengpid, S. (2017). The association of dietary behaviors and physical activity levels with general and central obesity among ASEAN university students. AIMS Public Health. 4: 301-13.

15. Vancelik, S., Gursel, S., Guraksin, A., Beyhun, E. (2007). Related Factors with Nutritional Habits and Nutrition Knowledge of University Students. TAF Preventive Medicine Bulletin. 6(4): 242-248.

16. Deliens, T., Van Crombruggen, R., Verbruggen, S., De Bourdeaudhuij, I., Deforche, B., and Clarys, P. (2016). Dietary interventions among university students: A systematic review. 105, 14-26.

17. Alghamdi, E., Farrash, M., Bakarman, M., and Mukhtar, A. (2018). Dietary Habits of University Students Living at Home or at University Dorm: A Cross-Sectional Study in Saudi Arabia. Global Journal of Health Science, 10:10.

18. Al Rethaiaa, A., Fahmy, A., and Al-Shwaiyat, N. (2010). Obesity and eating habits among college students in Saudi Arabia: a cross sectional study. Nutrition Journal, 9: 39

19. Nedaa, A., Al-Khamees. (2009). Food habits of university nutrition students: pilot study. Nutrition \& Food Science; 39 (5):499 - 502.

20. Mohamadi, N., Shobeiri, F., Khirolahei, A., Roshanaie, G. (2014). Nutritional patterns in Iranian university students comparison between dormitoryand non-dormitory states. Journal of Medical Research, (1): 001-5.

21. Lupi S, Bagordo F, Stefanati A, Grassi T, Piccinni L, Bergamini M, et al. Assessment of lifestyle and eating habits among undergraduate students in northern Italy. Ann Ist Super Sanità. 2015;51(2):154-61. 